\title{
Narrating Sovereignty: The Covenant Chain in Intercultural Diplomacy
}

\author{
Heather Hatton \\ University of Hull \\ Email: h.hatton@2017.hull.ac.uk
}

\section{Abstract}

This article considers Haudenosaunee recitals of the history of the Covenant Chain as a powerful communicative mechanism to define and assert sovereign identity and rights in the context of intercultural diplomacy. It reflects initially on the metaphorical language used to structure these historical narratives and how it enabled the Haudenosaunee to articulate self-understandings of their sovereignty. Contending that the narrative's main power stemmed from its application in specific diplomatic contexts, the article then examines three instances when the Haudenosaunee recounted the entire history of the Chain during mid-eighteenth century treaty councils with the British. It explores the reasons underpinning the narrative's use on these occasions and its overall implications. Finally, the article discusses the adoption of the narrative by one British diplomat, Sir William Johnson, considering his motivations for using the Covenant Chain and its intended effects.

\section{Keywords}

sovereignty; Covenant Chain; power; Haudenosaunee; intercultural diplomacy

The term 'Covenant Chain' derives from the English translation of the Haudenosaunee tradition that 'firm bonds of trust and solidarity are created by linking arms together'. ${ }^{1}$ Scholars have predominantly understood the Chain as a mechanism of diplomacy, a Haudenosaunee-British institution for sharing power, or an instrument utilised by the English to facilitate trade and territorial expansion. ${ }^{2}$ Others have considered its function as a metaphor, how it was used to reference particular Haudenosaunee-European alliances and how it worked to create and sustain

\footnotetext{
${ }_{1}^{1}$ Robert A. Williams Jr, Linking Arms Together: American Indian Treaty Visions of Law and Peace, 1600-1800, (Oxford University Press Inc., 1997), ch. 3, 4.

${ }^{2}$ Daniel Richter, The Ordeal of the Longhouse: The Peoples of the Iroquois League in the Era of European Colonization, (University of North Carolina Press, 1992), 150, Francis Jennings, The Ambiguous Iroquois Empire, (W. W. Norton \& Company, 1984), 373, William N. Fenton, The Great Law and the Longhouse: A Political History of the Iroquois Confederacy, (University of Oklahoma Press, 1998), 300.
} 
relationships based around trust and mutual respect. ${ }^{3}$ In the context of Haudenosaunee council oratory the Covenant Chain was also used to structure and articulate the history of Haudenosaunee-European relations. Despite frequent references to the Chain in the records of diplomatic transactions, scholars have yet to fully explore why the Haudenosaunee chose to narrate their history in this manner. ${ }^{4}$ Building on the idea that sovereignty is inextricably linked to a society's ability to construct its own history, this article argues that Covenant Chain narrations were a powerful communicative mechanism to define and assert sovereign identity and rights in the context of intercultural diplomacy. ${ }^{5}$ The narrative defined sovereignty in relation to ancestral territorial origin and as a careful balance of political autonomy and mutual obligation. The Chain narrative followed a general form when recited - what made it such a powerful statement was the particular diplomatic contexts in which it was employed. When strategically used, during specific treaty councils, the Covenant Chain narrative enabled the Haudenosaunee to express inherent sovereignty, demand contextually specific rights, and bring about 'right relations' with their British allies. ${ }^{6}$

Providing the first systematic analysis of the Covenant Chain narration as an expression of Haudenosaunee sovereignty this article considers how three Haudenosaunee nations, the Onondaga, Seneca and Oneida, recited the history of the Chain to assert sovereign rights in the context of three mid-eighteenth century treaty negotiations. Although the belief that 'pre-literate' indigenous societies lacked historical consciousness and were a 'people of myth' is now generally discounted, indigenous historical constructions and knowledge, contained with colonial documentation, have received little attention. ${ }^{7}$ Doubts concerning the veracity of indigenous history

\footnotetext{
${ }^{3}$ Francis Jennings, 'Glossary of Figures of Speech', in Jennings (ed.) The History and Culture of Iroquois Diplomacy: An Interdisciplinary Guide to the Treaties of the Six Nations and Their League, (Syracuse University Press, 1995), 116, Louise Johnston, 'The Covenant Chain of Peace: Metaphor and Religious Thought in Seventeenth Century Haudenosaunee Council Oratory, (PhD Dissertation, McGill University, 2004). ${ }^{4}$ Quentin Skinner, Visions of Politics: Regarding Method, Vol. I, (Cambridge University Press, 2002), 42, 102. 5. G. A. Pocock, 'The politics of historiography', Historical Research, Vol. 78, (2005), 12.

${ }^{6}$ John Borrows and Michael Coyle (eds.), The Right Relationship: Reimagining the Implementation of Historical Treaties, (University of Toronto Press, 2017), 3.

7John Duval and Kathleen Duval, 'Writing Translations, Writing History: Colonial American Voices and the Problem of Verticality', Early American Literature, Vol.53, (2018), 158, Deborah Doxtator, 'Inclusive and Exclusive Perceptions of Difference', in Germaine Warkentin and Carolyn Podruchny (eds.), Decentring the
} 
continue to prevent wider scholarly engagement and critical analysis. Such doubts stem from a belief in the superiority of the written record and deeply rooted understandings, within European culture, that history reveals the processes of social development. During the Enlightenment philosophers proposed that societies moved through a progressive sequence, from primitive to civilised.

'Primitive' societies, such as indigenous nations encountered in North America, were considered as incapable of possessing, or even constructing their own history. ${ }^{8}$ For Europeans, the purpose of history was the objective quest for historical truth and historical accounts were organised in a chronological manner. Constructions of the past which failed to conform with these understandings were dismissed, and societies who posed differing historical formulations classified as 'without history'.

Related to the theory of stadial historical development Enlightenment philosophers also proposed hierarchies of language based on societal progression. Although many colonists were impressed by the oratorical skills of indigenous speakers, eloquence during this period was theorised as 'linguistic poverty'. It was believed that indigenous people lacked the words to express abstract concepts, instead having to rely on figurative elements of speech to convey complex ideas. ${ }^{9}$ In the eighteenth century metaphorical language was severely criticised for being imprecise, deluding and manipulative. For example John Locke, one of the staunchest critics of figurative language, proclaimed metaphors served only to 'insinuate wrong ideas, move the passions, and thereby mislead the judgement'.$^{10}$ In comparison to indigenous languages which were heavily metaphorical, European languages were classified as civilised for they had 'transcended the figurative stage and become analytical. ${ }^{11}$ Europeans were thus thought to possess the linguistic capabilities necessary to accurately construct historical accounts. Such beliefs, it appears, continue to shape scholarly

Renaissance: Canada and Europe in Multidisciplinary Perspective, 1500-1700, (University of Toronto Press, 2001), 2.

${ }^{8}$ Eric Wolf, Europe and the People without History, (University of California Press, 2010), 16 -18.

${ }^{9}$ Sean Harvey, Native Tongues: Colonialism and Race from Encounter to the Reservation, (Harvard University Press, 2015), 22, see also William M. Clements, Native American Verbal Art: Texts and Contexts, (University of Arizona Press, 1996), 66.

${ }^{10} \mathrm{John}$ Locke, An Essay concerning Human Understanding, (London, 1825), 372.

${ }^{11}$ Harvey, Native Tongues, 44. 
thinking, with many considering oral histories as 'rich and useful' but lacking the 'specific time-stamped details' they crave. ${ }^{12}$ Yet confining historical constructions to one semiotic system alphabetic text - is immensely problematic for it continues to perpetuate imperialist attitudes of what constitutes 'real history' and overlooks historical perspectives recorded in non-alphabetic formats. ${ }^{13}$ By prioritising indigenous forms of communication, in the form of oral recitals of the Covenant Chain, this article seeks to counter the interpretative imbalance in early American history stemming from an overreliance on the written record.

Analysis of the diplomatic contexts in which the Haudenosaunee employed the Covenant Chain narrative is crucial to developing a greater understanding of the metaphor's function and power. Political councils were an important aspect of Haudenosaunee culture, predating European arrival in America. The Haudenosaunee Confederacy itself, comprising initially of five nations the Mohawk, Oneida, Onondaga, Cayuga and Seneca until the Tuscarora were incorporated in 1722, was established through a series of alliances dating sometime between 1400 and 1600 . The Confederacy was formed with the aim of ending a period of chronic warfare between these nations, and in response to external threats by common enemies. ${ }^{14} \mathrm{~A}$ Grand Council of chiefs was formed and met regularly to ensure peace was maintained. Councils were also a forum for inter-tribal diplomacy, in which negotiations over territory, trade, war and peace took place, and a venue in which cross-cultural alliances were established and sustained.

The Confederacy's commitment to peace and the idea that relationships needed to be frequently revisited and renewed, via customary forms, continued to influence Haudenosaunee diplomacy with Europeans. Councils were considered fundamental to the process of alliance building and maintenance of relations for they provided a venue for allies to negotiate and come to a consensus regarding terms governing specific relationships. ${ }^{15}$ For the Haudenosaunee councils were

\footnotetext{
${ }^{12}$ Duval and Duval, 'Writing Translations', 158.

${ }^{13}$ Birgit Brander Rasmussen, Queequeg's Coffin: Indigenous Literacies and Early American Literature, (Duke University Press, 2012), 4.

${ }^{14}$ Fenton, Great Law and the Longhouse, 72, 101, 130.

${ }^{15} \mathrm{Ibid}$., 103.
} 
about more than words, or written agreements, they were about renewing kinship ties, catching up on news and gathering information about events beyond Iroquoia. The Covenant Chain in this regard functioned as a 'civic narrative' for it reminded members of the Confederacy, and other nations the Haudenosaunee had extended membership of the Chain to, of the obligations of alliance. Europeans too considered councils as diplomatic forums, however they viewed such meetings, and associated diplomatic ritual, as preliminary to the real business of creating a legally binding written contract. Unlike the Haudenosaunee, it was the product, as opposed to the process of negotiation, which the British considered most important. ${ }^{16}$ In a world where such contrary views of diplomacy met, the Covenant Chain narrative functioned as means to remind the British of the importance of ongoing intercultural dialogue and stressed the need for frequent renegotiation of the terms of alliance.

With such differences in mind, in relation to what each society perceived as the purpose of treaty councils, it becomes clear that the context in which the Covenant Chain was employed was intrinsic to its meaning. Careful analysis of what Haudenosaunee orators were reacting to, what historical and political circumstances motivated their use of the Covenant Chain narrative, will aid interpretation and allow for a deeper understanding of this aspect of metaphorical language. ${ }^{17}$ Using a similar approach Mark Walters has argued that the Covenant Chain was a 'very particular form of intergovernmental discourse' that acted as a 'mechanism for developing just relationships. ${ }^{18}$ Certainly Covenant Chain narrations allowed the Haudenosaunee to remind the British of their rights as allies and to demand fairer treatment. However, such recitals of history were more complex, for the metaphorical language also allowed the Haudenosaunee to define and assert sovereign independence and rights, and thus functioned as a statement of power to challenge and undermine British territorial and judicial claims.

\footnotetext{
${ }^{16}$ Michael K. Foster, 'On Who Spoke First at Iroquois-White Councils', in Michael K. Foster, Jack Campisi and Marianne Mithun, Extending the Rafters: Interdisciplinary Approaches to Iroquoian Studies, (New York, 1984), 194, Colin G. Calloway, Pen and Ink Witchcraft: Treaties and Treaty Making in American Indian History, (Oxford University Press, 2013), 17.

${ }^{17}$ Skinner, Visions of Politics, 102.

${ }^{18}$ Mark Walters, 'Rights and Remedies in Common Law and Indigenous Legal Traditions', in Borrows and Coyle (eds.) Right Relationship, 204.
} 
Although explicit indigenous use of the term 'sovereignty' is absent from historic treaty documentation, the Covenant Chain demonstrates one way in which indigenous nations forcefully expressed political independence and rights under diplomatic agreement. As Craig Yirush notes, despite the acknowledgement that the early modern world was characterised by 'divided sovereignty' many scholars continue to overlook the 'legal, political and constitutional ideas' of indigenous nations. Those who have considered indigenous political speeches, made during intercultural diplomacy, have examined them for what they reveal about cultural contact rather than scrutinising the ideas and arguments the orations contain. ${ }^{19}$ However, political thought is not a Eurocentric construct, grounded in Greco-Roman ideals, it was present also in pre-modern non-Western societies. ${ }^{20}$ For the Haudenosaunee sovereignty was not a fixed notion, it was 'a historically contingent construct' based on conquest over other nations, ancestral claims to land, access to trade goods and hunting territory and the capacity to protect the people within your society. ${ }^{21}$ Envisioning sovereignty differently many British officials, especially in formal correspondence, represented the Haudenosaunee as subjects of the Crown, whose rights existed solely in the Crown's recognition of them. ${ }^{22}$ However, analysis of treaty council documentation presents a more complex picture; the British did not interact with the Haudenosaunee as they would with 'subjects' during many mid-eighteenth century diplomatic councils and the Haudenosaunee certainly were not passive recipients of rights. Translations of Haudenosaunee council oratory reveal that they continually reminded colonial officials of their sovereign identity and rights during diplomatic transactions which were of Native design and followed Native protocol.

\footnotetext{
${ }^{19}$ Craig Yirush, 'Since We Came out of this Ground': Iroquois Legal Arguments at the Treaty of Lancaster' in (eds.) Bruce P. Owensby \& Richard J. Ross, Justice in a New World: Negotiating Legal Intelligibility in British, Iberian and Indigenous America, (New York University Press, 2018), 118.

${ }^{20}$ J.G.A Pocock, 'On the unglobality of contexts: Cambridge methods and the history of political thought', Global Intellectual History, Vol.4, (2019), 3.

${ }^{21}$ Lauren Benton, 'Made in Empire: Finding the History of International Law in Imperial Locations', Leiden Journal of International Law, Vol. 31, (2018), 475.

${ }^{22}$ Dutch and English attitudes to native sovereignty were very different due to the political organisation of their respective homelands. For more see Penelope Edmonds, Settler Colonialism and (Re)Conciliation: Frontier Violence, Affective Performances and Imaginative Refoundings, (Palgrave, 2016), 42.
} 
The Covenant Chain was just one component of metaphorical language employed by the Haudenosaunee during treaty councils. Conceptual systems, it has been argued, are largely metaphorical and thus the way we think and understand the world is very much a matter of metaphor. ${ }^{23}$ Haudenosaunee metaphors were specifically drawn from understandings of alliance and the landscape which they inhabited. The Haudenosaunee channelled their political ideas through references to tools, to their environment, and to things that were specifically the products of intercultural diplomacy. For example, the metaphors of the canoe and hatchet are references to tools; the Great Tree of Peace and the path are references to the environment and the council fire and Covenant Chain are references to the products of intercultural diplomacy. Within these categories however, the Covenant Chain was the most politically powerful metaphor for it tangibly demonstrated a relationship of trust, care and respect between equally free peoples.

Metaphorical language was also deeply embedded within Haudenosaunee spiritual understandings. For example, the image of the council fire was related to the history of the Haudenosaunee Confederacy. According to oral tradition, Deganawidah, the Peacemaker, kindled a central fire at Onondaga and instructed it was to be kept burning. The Confederacy, Deganawidah stated, would remain alive so long as the fire burned. ${ }^{24}$ The idea of a perpetually burning fire influenced Haudenosaunee thinking regarding multicultural relations. To kindle and rekindle the council fire reflects the idea that alliances, and political agreements, need to be frequently renewed and their terms renegotiated in order to survive. The Great Tree of Peace was also linked to spiritual understandings. Deganawidah planted a great white pine at Onondaga, the heart of the Confederacy. He temporarily uprooted the tree, placed weapons of war in the hole created by the roots and then replanted the tree. ${ }^{25}$ When used during councils this metaphor was a means of expressing intentions of peace. Reference to the Great Tree's branches were also used to convey ideas about protection and shelter, and its roots used to express the extension of law and peace to

\footnotetext{
${ }^{23}$ George Lakoff and Mark Johnson, Metaphors We Live By, (University of Chicago Press, 2003), 124.

${ }^{24}$ Johnston, 'The Covenant Chain of Peace', 56-7.

${ }^{25}$ Ibid., 87.
} 
embrace all humankind. Significantly, during intercultural diplomacy, Europeans themselves also frequently employed the metaphors of the council fire and The Great Tree of Peace, aspects of figurative speech that formed part of the of the bundle of metaphors by which the Haudenosaunee understood and communicated their core political values.

Given its centrality to the two-row, or Kaswentha, tradition the metaphor of the canoe has garnered most scholarly attention. The underlying concept of Kaswentha is the idea of a 'separate-but-equal relationship between two entities based on mutual benefit and mutual respect', depicted visually on wampum belts by two parallel lines of purple wampum against a background of white shells. ${ }^{26}$ For both entities to maintain their freedom neither side is to attempt to 'steer the vessel [canoe] of the other as it travels along its own self-determined path. ${ }^{27}$ There has been much debate concerning whether Kaswentha is a pre or post-contact tradition. ${ }^{28}$ However, as Walters argues, regardless of its origin date the concept is useful for it allows for a deeper understanding of the boat-chain-mountain image contained within Covenant Chain recitals. The canoe imagery is also integrated with the homeland of the Haudenosaunee, a world of interconnected waterways. When used in diplomacy the canoe represented a literal 'jurisdictional space within a complex network of laws through which it must be navigated. ${ }^{29}$ On their arrival Europeans became part of this landscape, forming a separate jurisdictional space which indigenous peoples interacted with but did not subsume their political autonomy. ${ }^{30}$ By applying these ideas to the Covenant Chain narrative, the Chain can be seen to represent unification, an alliance of interdependence between two parties, but as the ship remained always moored at a distance from the great mountain, so too did the Europeans. This idea represented the political and sovereign independence of both parties and a commitment to not interfere in each other's affairs.

\footnotetext{
${ }^{26}$ Jon Parmenter, 'The Meaning of Kaswentha and the Two Row Wampum Belt in Haudenosaunee History' Journal of Early American History, Vol. 3, (2013), 84.

${ }^{27} \mathrm{lbid}$.

${ }^{28}$ For debates concerning the historic origins of Kaswentha see Kathryn V. Muller, 'Holding Hands With Wampum: Haudenosaunee Council Fires from the Great Law of Peace to Contemporary Relationships with the Canadian State', (Ph.D. Dissertation, Queen's University, 2008) and Parmenter, 'The Meaning of Kaswentha'. ${ }^{29}$ Walters, 'Rights and Remedies', 196.

${ }^{30} \mathrm{lbid}$.
} 
Despite Enlightenment philosophers' criticisms the British, during the eighteenth century, also frequently used metaphors to explain political ideology and relationships of power. 'The body politic' for example was a metaphor in which the state and its institutions were conceived as a biological body. The 'ship of state' likened the governance of state to the command of a vessel and the 'Great Chain of Being' depicted a hierarchical structure, ordained by God, which placed all matter and life in a particular place in an ascending chain. Why Covenant Chain narrations survive in the historical record is perhaps linked to the appreciation certain British officials possessed of the significance, and power, of political metaphor.

Similarly, Covenant Chain narratives may have survived translation as they explained power relations in terms of ancestral origins, a means of understanding politics the British also shared. Political origin stories were used by the British to articulate the beginnings of politics, describe and justify the balance of power and explain the rights of citizens. ${ }^{31}$ As with Hobbes' social contract discourse, they were often used to incite action and bring about positive political change. Autochthonous origin stories, defining origins of a particular race within the earth itself, were also popular in Western political discourse as evidenced with Plato's Timaeus. ${ }^{32}$ This origin story was used to assert authentic citizenship and exclude outsiders from true membership of the state. ${ }^{33}$ That political origin stories were customary in both societies facilitated cross-cultural understanding and allowed the British to appreciate the significance of the Covenant Chain narrative. The popularity of figurative expression in eighteenth century British politics and the shared used of political origin stories perhaps explains why one British official, Sir William Johnson, adopted this aspect of indigenous metaphorical language to express British political power during diplomatic transactions with the Haudenosaunee.

\footnotetext{
${ }^{31}$ Joanne H. Wright, Origin Stories in Political Thought: Discourses on Gender, Power and Citizenship, (University of Toronto Press, 2004), 59.

${ }^{32}$ Ibid., 4.

${ }^{33} \mathrm{lbid}$.
} 
The Covenant Chain metaphor was 'a synthesis of words, concepts and political aspirations derived from two very different linguistic and cultural traditions. ${ }^{34}$ The term 'chain' for example was perhaps an English (mis)translation for the indigenous expression of 'linking arms in friendship' that became common parlance. ${ }^{35}$ The word 'covenant' also derives from English terminology but has its roots in the Latin verb convenire, meaning to 'agree'. For the British, this term had biblical origins, being a particularly prominent concept in the Old Testament in which biblical covenants were made with Moses, Abraham and David. The term 'covenant' was understood as an agreement which brings about a relationship of commitment between God and his people and was a widespread concept in seventeenth century Protestant Europe. ${ }^{36}$ Conversely, the idea of a covenant had a basis within Haudenosaunee understandings of alliance, as relationships structured around bonds of mutual obligation, trust and respect. It was also reflected in Haudenosaunee beliefs that the Creator 'bears witness' to agreements made between human parties during diplomacy, and affirms the solemnity of agreement formed. ${ }^{37}$ Although there were stark differences in what the Haudenosaunee and British considered as the aim of treaty conferences, the Covenant Chain, as the product of cross-cultural interaction, reflected the common desire of both parties to meet often and reach a consensus. $^{38}$

Although shared conceptual understandings helped create the term 'Covenant Chain' one reason the metaphor was so powerful was that it expressed a particular understanding of relationships, one grounded in Haudenosaunee worldviews. The format of the Chain narrative was relatively consistent, with the European vessel tied to the indigenous landscape being the basic image consistently conveyed during oral recitals. Usually the orator began the narrative by

\footnotetext{
${ }^{34}$ Mark Walters, 'Brightening the Covenant Chain: Aboriginal Treaty Meanings in Law and History after Marshall, Dalhousie Law Journal, Vol. 75, (2001), 81.

${ }^{35}$ Fenton, Great Law and the Longhouse, 349.

${ }^{36}$ Johnston, 'The Covenant Chain of Peace', 154.

${ }^{37}$ Richard W. Hill and Daniel Coleman, 'The Two Row Wampum-Covenant Chain Tradition as a Guide for Indigenous-University Research Partnerships', Cultural Studies - Critical Methodologies, (2018), 9-10. ${ }^{38}$ Jane Merritt, 'Metaphor, Meaning and Misunderstanding: Language and Power on the Pennsylvania Frontier', in Andrew Cayton and Fredrika Teute (eds.), Contact Points: American Frontiers from the Mohawk Valley to the Mississippi, 1750 - 1830, (University of North Carolina Press, 1998), 72-74.
} 
explaining how the Haudenosaunee anchored a European vessel, sometimes specifically identified as a Dutch ship, to the shore on its arrival with grass cord or bark. The orator would typically then proceed to recount the ways in which the bonds of friendship evolved over time. For example, the grass cord was replaced by an iron Chain to represent the strengthening of the Haudenosaunee-Dutch relationship which was later changed to a silver Chain to represent the even stronger union between the Haudenosaunee and the British. Changes to the method of securing the Chain also symbolised the strengthening of the respective alliances. The need to keep the Chain 'bright' and free from rust was also repeated, reflecting the Haudenosaunee belief that links of kinship must be regularly confirmed and renewed via customary forms. Covenant Chain narratives were a means to articulate sovereign independence in relation to European arrival in North America. Significantly, the narrative depicts indigenous people as accepting and securing European vessels to the landscape, signifying that European presence in indigenous territory was subject to indigenous permission.

As can be seen from the narrative, the idea of alliance began as a naturalistic concept, the original means of binding the European vessel to the shore was with organic materials - grass and bark. After the arrival of Europeans, the manner for metaphorically representing a political alliance was changed to a chain to better reflect European ideas. The bonds of alliance became an iron or silver chain, materials foreign to Haudenosaunee society. Pictorial representations of the Chain produced by the British demonstrate their understanding of this metaphorical expression, and how it changed over time. Figure 1, a seal used by Sir William Johnson produced shortly after his appointment as Superintendent of Indian Affairs, depicts an endless chain held by six indigenous and one white figure. ${ }^{39}$ Within the chain are a number of images including the Great Tree of Peace, a European vessel and a canoe. This image is a mixture of Haudenosaunee and British ideas of alliance, but one more heavily influenced by indigenous understandings. The Haudenosaunee idea of an alliance of interdependence forged through the joining of hands is represented in this image as well

${ }^{39}$ The Papers of Sir William Johnson, Vol. XIII, (Albany, 1921), 98 (hereafter, PWJ). 
as the notion of political autonomy depicted by the vessels sailing in parallel. ${ }^{40}$ Furthermore, the depiction of the chain as endless was perhaps influenced by circle wampum, which represents the fifty chiefs of the Confederacy standing hand-in-hand in unity around their people. The joining of hands symbolises that all chiefs are of equal rank and hold equal responsibilities toward their people. ${ }^{41}$ Arguably this idea of political equality influenced the design of Johnson's first seal.

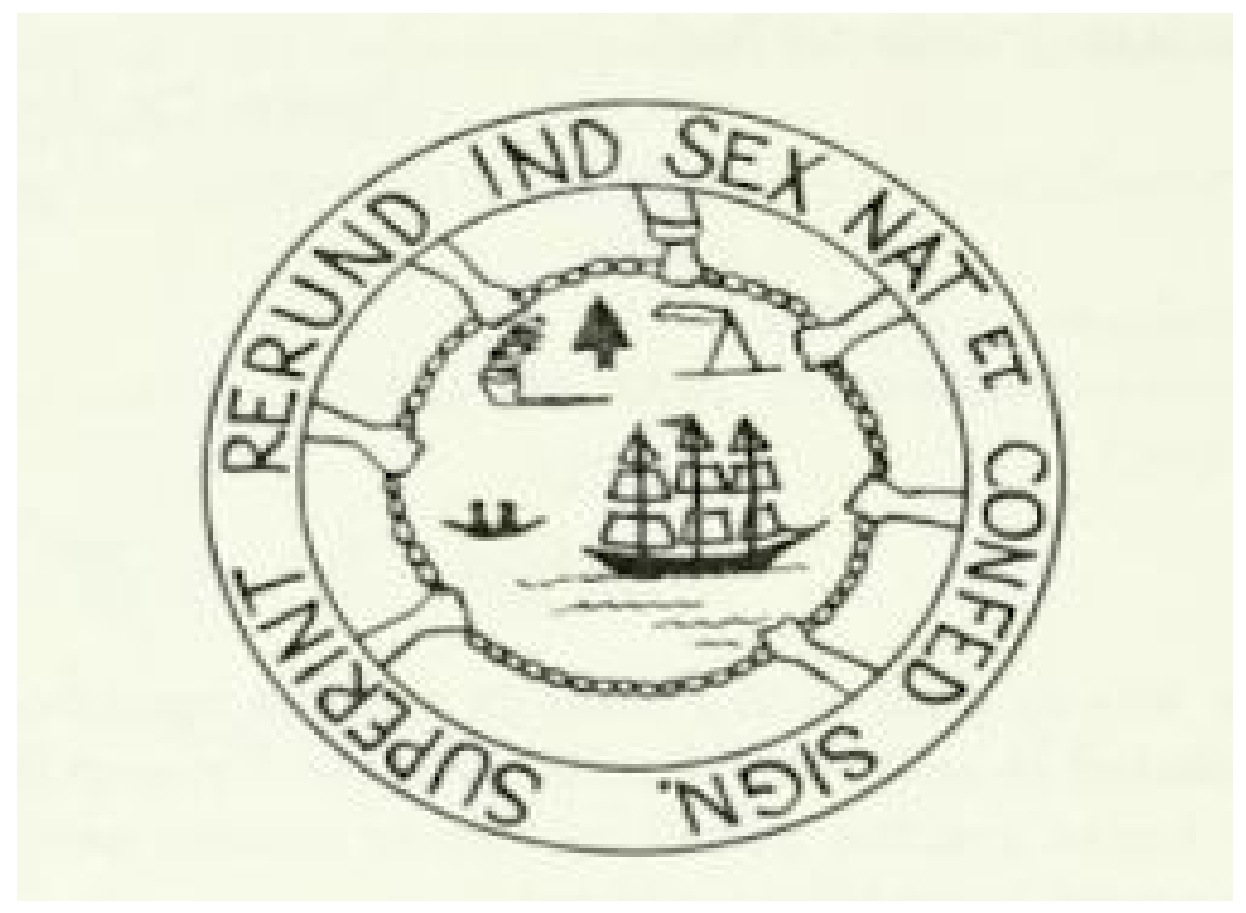

Fig. 1.

The image of Johnson's 1770 seal, depicted in figure 2, however demonstrates a considerably changed understanding of intercultural alliance, influenced more by British conceptions. ${ }^{42}$ Representations of Indigenous political ideology are still present, in images of the Great Tree of Peace and the council fire, but the Covenant Chain is no longer directly connecting British and Haudenosaunee allies, it hangs from the Tree of Peace, perhaps as reminder of the origins of their relationship. The naturalistic idea of alliance and implications of relational

\footnotetext{
${ }^{40}$ For specific Haudenosaunee references to forging alliance through the joining of hands see LAC, RG 10, Commission for Indian Affairs, Albany, reel C-1220, 30th May 1723, 21a and $4^{\text {th }}$ July $1730,322$.

${ }^{41}$ Hill and Coleman, 'The Two Row Wampum', 10.

${ }^{42}$ Image taken from John W. Barber and Henry Howe, Historical Collections of the State of New York, (New York, 1846), 173.
} 
interdependence are not shown; British officials sit on one side of the fire and the indigenous representatives on the other noticeably unconnected with hands in their laps. This indicates disunity between the Haudenosaunee and the British, and perhaps among the nations of the Confederacy. Also, less present in this image is idea of political independence. Instead Johnson, the figure presenting the medal, appears to be leading council proceedings and rewarding his indigenous allies for remaining committed to previous agreements. The iconography here is at odds with how the Haudenosaunee understood the Covenant Chain.

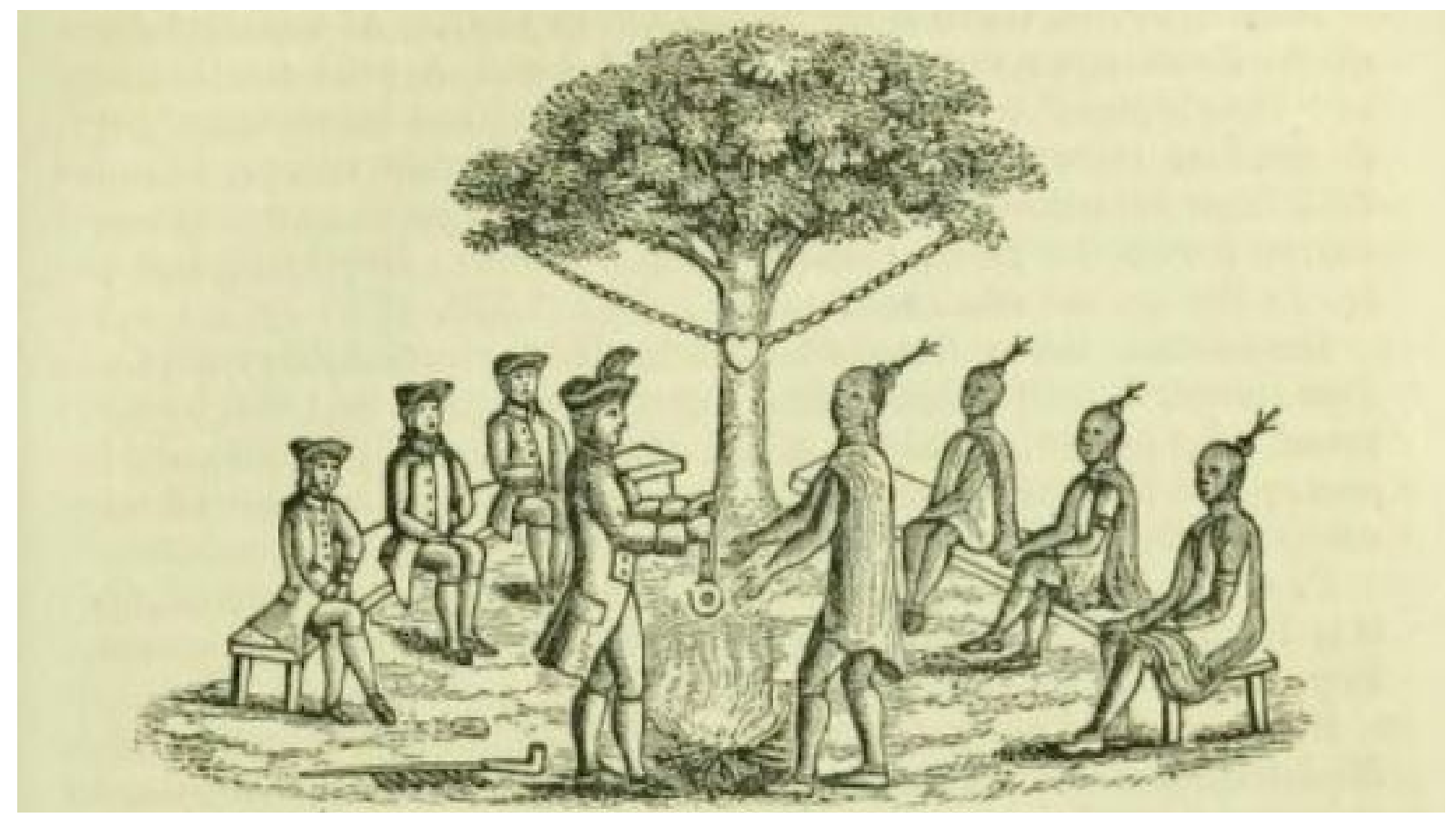

Fig. 2. 
Although the Haudenosaunee allowed their understanding of Covenant Chain to be translated into European terminology and iconography, they retained their own naturalistic concept of alliance as evidenced visually on wampum belts. The depiction of the Chain rendered on wampum belts was not one of metal but was represented through the image of linked arms. As can be seen on the 24 nations belt (see fig.3, middle belt) the Covenant Chain was an indigenous understanding of a relationship with intruders which acknowledged the interdependent nature of parties within an alliance through the union of bound hands/arms. ${ }^{43}$ However, as demonstrated by the European vessel remaining forever moored offshore, at a great distance from the mountain, it was a conception of alliance but not at the cost of losing political independence. Thus, although the terminology 'chain' was of European origin recitals of the history of the Covenant Chain allowed the Haudenosaunee to forcefully assert their sovereign identity and demand particular rights precisely because the narrative remained intrinsically embedded within Haudenosaunee worldviews.

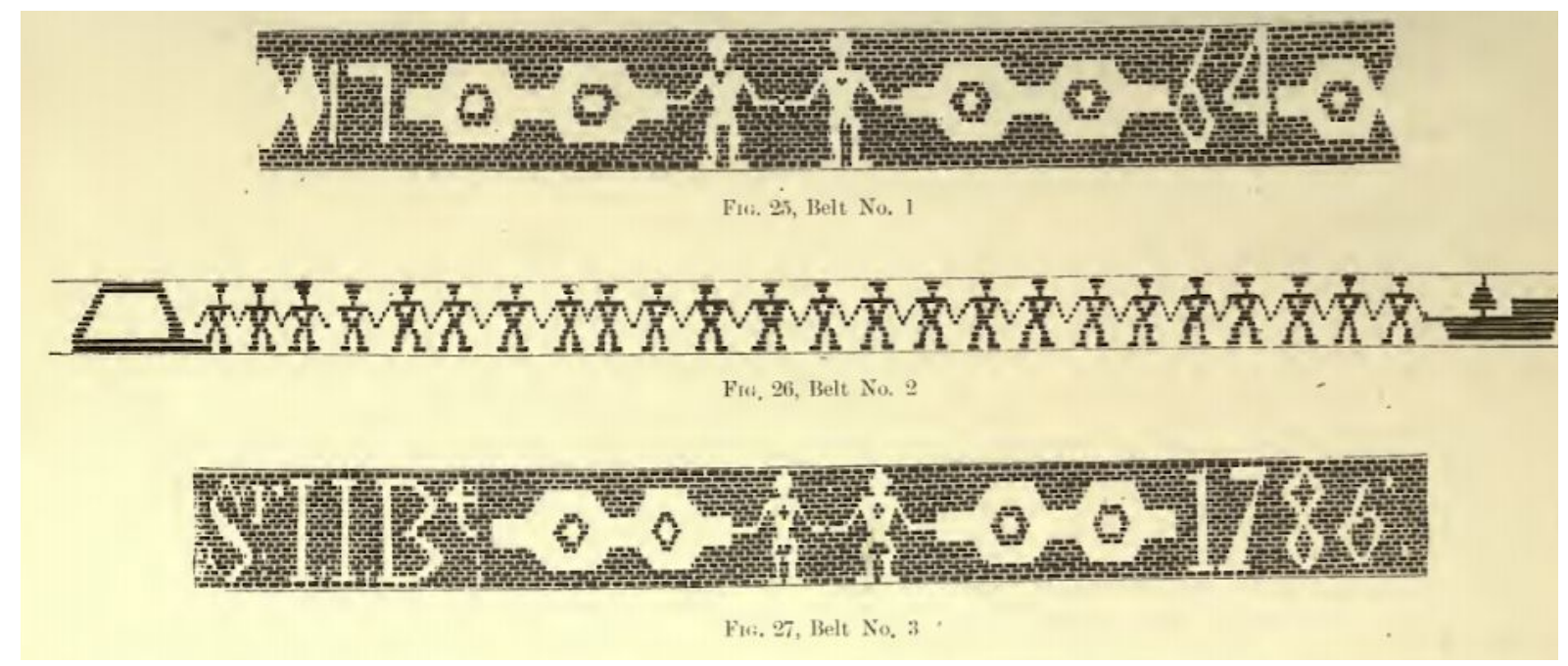

Fig. 3.

Although discussion of the Covenant Chain recital's general form is helpful for explaining its significance and power, careful consideration of the contexts in which the Haudenosaunee used this historical narrative demonstrates what Haudenosaunee speakers were trying to achieve when

\footnotetext{
${ }^{43}$ Image taken from Royal Ontario Museum, $16^{\text {th }}$ Annual Archaeological Report 1901, (Toronto, 1902), 53.
} 
expressing their history in this manner. Such analysis will enhance our understanding of intercultural diplomacy and of the spaces in which sovereignty was created in early America. Focusing on three eighteenth century treaties this paper analyses three instances in which the Haudenosaunee recounted the entire history of the Covenant Chain: at the 1744 Treaty of Lancaster, the 1748 Treaty of Logstown and the 1768 Treaty of Fort Stanwix. It also considers how this aspect of metaphorical language was adopted by Sir William Johnson, Superintendent of Indian Affairs from 1755, to assert British sovereignty and demonstrate his awareness of the Covenant Chain's function in shaping British-Haudenosaunee relations.

\section{Treaty of Lancaster, 1744}

At the 1744 Treaty of Lancaster the Onondaga spokesman, Canasatego, used the Covenant Chain narrative to challenge British territorial claims. Canasatego's speech has received much attention from historians focusing on the four sentences in which Canasatego advocates colonial unity and whether this influenced the 1754 Albany Plan of Union. A closer analysis of the context in which Canasatego spoke however reveals his speech was predominantly concerned with retention of internal sovereignty within an alliance. ${ }^{44}$

The Lancaster treaty council met to address the ongoing land dispute between Virginia, Maryland and the Six Nations, specifically the Six Nations' claim by right of conquest to the Shenandoah Valley, an area of land bordering the two colonies. The Maryland Commissioners challenged the Six Nations' claim, stating they possessed rights to the region through purchase. Presenting deeds to prove they had legally acquired the land from the Susquehannock Indians, the commissioners argued they had been in possession of the area for 'above one hundred years. ${ }^{45}$ The Onondaga leader, Canasatego, countered the commissioner's claims, declaring 'long before one hundred years our ancestors came out of this very ground [and] have remained here ever since.' The British 'came out of the ground in a country that lies beyond the seas.' It was to this land,

\footnotetext{
${ }^{44}$ Samuel B. Payne, Jr. 'The Iroquois League', William and Mary Quarterly, Vol. 53, (1996), 614.

${ }^{45}$ Julian P. Boyd (ed.), Indian Treaties printed by Benjamin Franklin, 1736-1762, (Philadelphia, 1938), 48-49.
} 
Canasatego argued, that the British 'have a just claim'. We are your 'elder brethren', the Onondaga leader proclaimed, and the land belonged 'to us long before you knew anything of them. ${ }^{46}$ Here Canasatego's words were, in part, shaped by the Haudenosaunee Creation story wherein the Creator formed humans from clay and brought them to life with his breath. ${ }^{47}$ Yet his declaration was not purely spiritual it was also politically motivated; asserting that the Haudenosaunee were born of the soil allowed Canasatego to assert natural title to the land the Maryland Commissioners were claiming through right of purchase.

That Canasatego declared the Haudenosaunee as 'elder brethren' of the Maryland Commissioners also warrants attention. It may initially appear, and perhaps appeared to the Commissioners, that Canasatego was asserting his authority through a hierarchical familial relationship structure. However, unlike the British the Haudenosaunee did not base their concepts of the family on a system of primogeniture, in which the elder son possesses more power than the younger especially regarding property rights. Haudenosaunee metaphors of fictive kinship were based around the idea that siblings possessed particular responsibilities based on age and experience. In fact, in Haudenosaunee languages relational terms like brother are verbs, 'emphasising the doing of a relationship rather than presenting it as a fixed identity. ${ }^{48} \mathrm{~A}$ brother was thus expected to do 'brothering', and an elder brother, as a person who possessed more experience than younger siblings, was expected to initiate brothering actions. ${ }^{49}$ In the context of Canasatego's speech it could be argued that he was reminding the Commissioners of their responsibility to listen and pay heed to the knowledge of their elder brother and thus accept the Haudenosaunee's ancestral land claims.

After reminding the Commissioners of their responsibility to respectfully accept the wisdom of their elder sibling Canasatego then proceeded to recount the history of the Covenant Chain to

\footnotetext{
${ }^{46}$ lbid., 51.

${ }^{47}$ Susan M. Hill, The Clay we are Made of: Haudenosaunee Land Tenure on the Grand River, (University of Manitoba Press, 2017), 126.

${ }^{48} \mathrm{Hill}$ and Coleman, 'The Two Row Wampum', 12.

${ }^{49} \mathrm{lbid}$.
} 
reassert the historic, and ongoing, territorial claims of the Six Nations. He explained how the Haudenosaunee initially forged a relationship with the Dutch by tying their vessel with rope to bushes on the shore. To show how the relationship strengthened, Canasatego described how the method of securing the vessel had evolved over time - the rope was transferred from the bushes and re-attached to a cluster of trees, then to a big rock and finally to a mountain. To symbolise how the bonds of friendship were strengthened upon English arrival, Canasatego recounted how the English Governor at Albany requested the rope of alliance be changed to a silver chain as this material would be 'much stronger and would last forever.' The Chain, symbolising an alliance between the British and the Haudenosaunee, had 'lasted ever since. ${ }^{50}$ Thus Canasatego reminded the Maryland Commissioners of the nature of their alliance, that it was a relationship between distinct sovereign entities who were entangled in a web of interdependence. ${ }^{51}$

Then recalling the 1686 Dongan deed, a deed of territorial cession by the Haudenosaunee to New York, Canasatego spoke of how the British often violated treaty agreements. ${ }^{52}$ He reminded his audience of New York Governor Thomas Dongan, who advised the Six Nations to put the Susquehanna lands under his protection to prevent encroachers. Dongan, however, redrafted this deed as a land grant and then sold the land it described to William Penn. Canasatego not only questioned British integrity in relation to treaties, he also questioned the value of such 'pen-and-ink work' as a means of recording history. The deeds of the Maryland Commissioners were valid when originally signed, in the sense that at this time the Susquehanna Indians owned the land. However, Canasatego claimed that they were invalidated by the Six Nation conquest of the Susquehanna. Furthermore, Maryland and Virginia settlers were occupying lands on the Potomac, an area which now belonged to the Six Nations by right of conquest but had never been sold by the Susquehanna Indians.

\footnotetext{
${ }^{50} \mathrm{Ibid}, 51-52$.

${ }^{51}$ Dale Turner, This is Not a Peace Pipe: Towards a Critical Indigenous Philosophy, (University of Toronto Press, 2006), 54.

${ }^{52}$ Boyd (ed.), Indian Treaties, 52.
} 
Six Nation claims to conquest have been treated sceptically by many historians. Some believe they were a Haudenosaunee 'fiction' whereas others view them as a kind of British 'donation', in that recognising Haudenosaunee claims to conquest in tandem with seeing them as dependents would allow the British to argue that all territory conquered by the Haudenosaunee also belonged to them.$^{53}$ However, such arguments are predicated on European understandings of conquest and overlook the possibility that the Haudenosaunee may have possessed different understandings of the term. Unlike Europeans the primary aim of war for the Haudenosaunee was not territorial conquest, its purpose was to take captives who were incorporated into Haudenosaunee society to replace deceased members of the Confederacy. ${ }^{54}$ The Haudenosaunee adopted members of the Susquehanna in the 1670 s following the conclusion of the Haudenosaunee-Susquehannock wars and thus as Ononadaga spokesman Tachanoontia argued at Lancaster, the Susquehanna were 'now a part of our nations, and their lands at our disposal. ${ }^{55}$ As Yirush argues Haudenosaunee claims to territory by right of conquest were a synthesis of European and Haudenosaunee political ideas, one 'which retained the older idea of a mourning war leading to the incorporation of defeated foes as kin alongside the European idea of conquest rights to land' ${ }^{56}$ Canasatego's claim to the Potomac lands due to the adoption of members of Susquehanna Indians thus enabled him to highlight that Maryland and Virginia settlers were occupying this area without title, without the permission of the Haudenosaunee and in direct opposition to the mutual obligations of alliance as defined by the Covenant Chain.

Framing his entire argument in relation to the history of the Covenant Chain allowed Canasatego to assert the Six Nations' identity as a sovereign power and challenge the legitimacy of European constructions of history recorded in land deeds. The deeds presented by the Maryland Commissioners, as Canasatago argued, did not relate to lands on the Potomac. The Commissioners

\footnotetext{
${ }^{53}$ Colin G. Calloway, The Indian World of George Washington: The First President, the First Americans, and the Birth of the Nation, (Oxford, 2018), 34, Jennings, Ambiguous Iroquois Empire, 11.

${ }^{54}$ For more on mourning wars see Richter, Ordeal of the Longhouse, 32-38.

${ }^{55}$ Boyd (ed.), Indian Treaties, 56.

${ }^{56}$ Yirush, 'Since We Came Out of this Ground', 132.
} 
were attempting to use a historical document to claim rights to an area not included in their deeds. The Potomac Canasatego asserted had not been 'possessed one hundred years, no, nor above ten years' by Maryland ${ }^{57}$ In light of this, Canasatego demanded that the British consider the Six Nations' recent conquest of the Susquehanna, incorporate this into their historical constructions, and compensate the Six Nations for the Potomac lands. Although the Maryland and Virginian Commissioners refused to accept the Six Nations' territorial claims, Canastego's challenge was successful. Both colonies paid five hundred pounds for deeds to the Potomac and gave assurances that the Six Nations would maintain their right to pass through the area.

\section{Treaty of Logstown, 1748}

A second example of the strategic use of the Covenant Chain narrative is at the 1748 Logstown Treaty. Here the Seneca used the Chain to explain and justify the actions of their warriors, in taking two traders hostage, as a response to British disregard for the obligations of alliance. The Senecas' reasons for employing the Chain narrative were twofold; they were seeking to diffuse conflict and maintain peaceful relations with the British as well as reinforce the idea allies should not act in ways that would compromise the obligations of mutual alliance. During the 1740 s, two spheres of Six Nations influence developed, one at Onondaga and the other in the Ohio Valley at Logstown. Groups of Seneca, keepers of the western door of the Haudenosaunee Confederacy, migrated to the Ohio region in this period and formed multi-ethnic villages, with members of the Delaware and Shawnee nations. Due to the cultural composition of these villages the Seneca gradually began to develop different identity traits, distinct from the Haudenosaunee residing near the central council fire of the Confederacy at Onondaga. ${ }^{58}$ However, despite their differences, the Seneca speakers at Logstown used the Covenant Chain narrative in the same way as Canasatego.

\footnotetext{
${ }^{57} \mathrm{Ibid}$.

${ }^{58}$ Michael N. McConnell, A Country Between: The Upper Ohio Valley and its Peoples, 1724-1774, (University of Nebraska Press, 1997), 21.
} 
During the Logstown treaty council, the Seneca narrated the history of their relations with the British to Conrad Weiser, Pennsylvania's Indian agent and translator. The main reason Weiser had been sent to Logstown was due to the region's geographical importance; it was effectively the gateway to the Ohio and the Pays des Illinois and Pennsylvania sought to establish a foothold in the area by securing the allegiance of the Ohio Indians and prevent them allying with the French. ${ }^{59}$ In addition he was also ordered to obtain information concerning two South Carolina traders captured by the Seneca and to negotiate for their release. ${ }^{60}$ Tanaghrisson, the Seneca chief known to the British as the 'Half-King', used Covenant Chain metaphorical language to respond to Weiser's demands for information. Tanaghrisson explained how the Six Nations had initially forged a relationship with the British through tying their vessel by rope to the bushes, and then to a large tree. At the request of the English, the rope was exchanged for a silver chain to prevent breakage and was affixed to the 'mountains in the five Nations' Country.' This Chain, Tanaghrisson explained, bound the Six Nations and the British together in friendship and they had become 'all tyed by our arms together with it'. ${ }^{61}$ However, evil spirits had influenced the Seneca warriors who had taken the prisoners. Now they wished to remove the hatchet and bury the incident in a bottomless pit so 'it may not harm the chain of friendship. ${ }^{62}$

Reading this section alone one could conclude the Seneca were using the Covenant Chain as a plea that their warriors' recent actions should not jeopardise their long-standing alliance. However, reassessing what Tanaghrisson said within the context of his entire speech reveals the Seneca were reminding the British of the obligations of alliance as well as rebuking the British for provoking their warriors. Covenant Chain metaphorical language allowed the Seneca to remind the British that theirs was a relationship between sovereign powers tied together by mutual obligation. Tanaghrisson's metaphor of 'tyed arms' also stressed that this was a horizontal rather than top-down relationship.

\footnotetext{
${ }^{59}$ Minutes of the Provincial Council of Pennsylvania, Vol. V, (Harrisburg, 1851), 121 (hereafter, MPCP).

${ }^{60} \mathrm{Ibid} ., 304$.

${ }^{61}$ lbid., 353.

${ }^{62}$ Ibid., 353.
} 
Each party was a sovereign and equal partner rather than a subordinate and a superior. ${ }^{63}$ One of the most important obligations binding each party was mutual respect. The British, Tanaghrisson argued, had shown disrespect for their relationship when they continued to trade with the Six Nations' enemy, the Catawba, even after being told not to do so. Six Nations' warriors, he explained, 'often found that the Englishmen betrayed them to their enemy'. ${ }^{64}$ It may be that Tanaghrisson was referring generally to certain English traders who betrayed the position of Haudenosaunee warriors to the Catawba. ${ }^{65}$ However, analysis of the historic record reveals the Seneca warriors were likely reacting to actions committed by the particular traders in question. It appears one of the prisoners, George Haig, was captured in retaliation for an incident in which he had seized and released Catawba prisoners held by the Haudenosaunee. ${ }^{66}$ Although we cannot be certain of the warriors' motivations what the Seneca capture of the traders demonstrates is sovereign action in response to offense. Such behaviour was a clear warning to the British of what would happen if British traders continued to ignore requests not to trade with the Catawba and meddle in inter-tribal affairs.

Using a powerful metaphor to remind the British of the history of their relationship, before revealing the reason behind the Seneca warriors' actions, gave weight to Tanaghrisson's claim that the British were partly culpable in relation to the Carolina incident. The historical narrative reaffirmed the idea that for an alliance to be successful both parties needed to treat each other respectfully, and an important part of this was adhering to each other's wishes. The British provided some provocation by failing to respect the Six Nation's request that they cease trading with the Catawba. Combined, the actions of the British traders and Six Nation warriors threatened to damage the tradition of cooperation that had existed between their societies. Tanaghrisson demonstrated his willingness to ensure the obligations of the British-Six Nations alliance were observed by

\footnotetext{
${ }^{63}$ For more on this, see Timothy Shannon, Indians and Colonists at the Crossroads of Empire, (Cornell University Press, 2000), 22.

${ }^{64} \mathrm{MPCP}, \mathrm{V}, 353$.

${ }^{65}$ Joseph Walton, Conrad Weiser and the Indian Policy of Colonial Pennsylvania, (Philadelphia, 1900), 190.

${ }^{66}$ James Adair, The History of the American Indians, (London, 1775), 344.
} 
releasing one prisoner, Mr Brown, to Weiser ${ }^{67}$ Here the Covenant Chain narrative functioned as a diplomatic tool that diffused conflict, for it emphasised that allies did not go to war with one another over disagreements, and that issues should be resolved peacefully via negotiation. It also allowed the Seneca to assert their identity as a sovereign power and demand their rights to reciprocal treatment and respect as politically independent parties in alliance. ${ }^{68}$

\section{Treaty of Fort Stanwix, 1768}

The Covenant Chain narrative was also effectively employed by an Oneida spokesman during the 1768 Treaty of Fort Stanwix. This treaty, which moved the boundary established by the 1763 Royal Proclamation further west, saw the Six Nations cede an enormous tract of land to the Crown that was largely occupied by the Ohio Haudenosaunee, Delaware and Shawnee. Historians have mainly considered Sir William Johnson and the Six Nations' actions at this treaty as being motivated by self-interest, but others argue such a reading accords insufficient attention to Oneida and Mohawk perspectives, nations most threatened by the boundary line extension. ${ }^{69} \mathrm{In}$ fact, both nations frustrated Johnson's plans by refusing to extend the boundary line north of Canada Creek and by demanding equal usage of the carrying place. Despite Johnson's efforts, the Oneida insisted that their rights to hunt, travel and trade, and sell unpatented land be maintained.

At issue was the question of where the boundary line lay in relation to the Oneida 'carrying place', a trade portage that linked the Mohawk River and Wood Creek. Initially, the Oneida insisted the boundary should lie east of the carrying place because of the employment opportunities the area offered them. However, after two days of private negotiations the Oneida agreed to move the boundary further west, in exchange for an additional six hundred pounds and on the condition they

\footnotetext{
${ }^{67}$ George Haig it transpires was murdered by his captors see, MPCP, V, 347.

${ }^{68}$ William M. Clements, Oratory in Native North America, (University of Arizona Press, 2002), 98, Williams, 'Linking Arms Together', 990.

${ }^{69}$ R.Douglas Hurt, The Indian Frontier, 1763 - 1846, (University of New Mexico Press, 2002), 13, Calloway, Pen and Ink Witchcraft, 8, William Campbell, Speculators in Empire: Iroquoia and the 1768 Treaty of Fort Stanwix, (University of Oklahoma Press, 2012), 6-8.
} 
retained equal access to trade. ${ }^{70}$ When publicly confirming their final resolution, the Oneida used the Covenant Chain narrative to assert their continued rights to hunt, live free from interference and sell unpatented land on the British side of the line. The Oneida spokesman began by reminding Johnson how the Haudenosaunee had kindly received the 'inconsiderable and weak' British on their arrival to America, and how the Haudenosaunee had 'entered into a Covenant Chain' with the newcomers. The Oneida speaker then reiterated, in the usual manner, how the chain's material had been made stronger and how the British had, over the years, continually polished the chain to prevent it looking dull. He then affirmed that the Oneida would renew the Covenant Chain and would abide by it, so long as British would also 'preserve it strong and bright' ${ }^{71}$ Here the Covenant Chain metaphor was used by the Oneida to remind the British that the survival of their alliance depended upon the constant renewal and renegotiation of the terms of their relationship. The British were attempting to impose new terms for this relationship through the 1768 boundary line, but the Oneida reminded them that their acceptance came with conditions.

The Oneida argued that the boundary line should be 'inviolably observed' to prevent future attempts by the provinces to invade under old deeds. ${ }^{72}$ The Covenant Chain metaphor gave the Oneida a context within which to affirm their hunting rights, even on the British side of the line. The Oneida spokesman also demanded that all unpatented land east of the boundary belonging to members of the confederacy should be considered as their 'sole property and at their disposal both now, and so long as the sun shines.' He also insisted that recent land arrangements be considered 'independent of the boundary' so the Haudenosaunee would not lose the benefit of sale. ${ }^{73}$ This important clause underscored Haudenosaunee control over the remaining land east of the boundary and emphasised their right to sell lands to whomever they pleased. ${ }^{74}$ The Mohawks' refusal to

\footnotetext{
${ }^{70}$ E. B. O'Callaghan (ed.), Documents Relative to the Colonial History of the State of New York, Vol. XIII, (Albany, 1857), 125 (thereafter, DRCHNY).

${ }^{71}$ lbid., 126.

${ }^{72} \mathrm{lbid}$., 127.

${ }^{73} \mathrm{lbid} ., 128$.

${ }^{74}$ Campbell, Speculators in Empire, 160.
} 
extend the boundary line 'more favourably to the West of New York' also prevented Johnson from securing a larger area for the Crown. ${ }^{75}$ Articulating their boundary conditions in the context of the Covenant Chain narrative gave greater authority to Oneida's demands, demonstrated how all parties had the responsibility of frequently revisiting and renegotiating the terms of an alliance, and reminded all involved that the Oneida's demands were part of that ongoing negotiation process.

\section{Sir William Johnson and the Covenant Chain}

As a shared metaphor the Covenant Chain was frequently used by the British during intercultural diplomacy. However, except for Sir William Johnson, it appears British officials did not recount the history of the Chain during diplomatic transactions - an observation which confirms the narrative's particular power as Haudenosaunee expression of sovereignty. ${ }^{76}$ Johnson, who from 1755 was the Crown's Superintendent of Indian Affairs for the northern colonies, was an exceptionally skilled diplomat. Both European and Native American contemporaries acknowledged his ability. Peter Wraxhall, a British official in New York, noted how Johnson's fair-trading practices and 'his friendly and humane behaviour' meant he held 'great sway and influence' over the Indians. ${ }^{77}$ Equally revealing of Johnson's diplomatic skills are the words of Mohawk chief Theyanoguin, known to the English as Hendrick, who on trying to get Johnson reinstated as Indian agent for the Six Nations affairs, proclaimed 'his knowledge of our affairs made us think him one of us (an Indian). ${ }^{78}$

Johnson's intimate knowledge of Haudenosaunee diplomatic custom stemmed from regular and close contact with this indigenous group, particularly the Mohawk nation. Johnson established relations with neighbouring Mohawk communities through his trading activities, and further

\footnotetext{
${ }^{75}$ PWJ, VI, 492. See also PWJ, XII, 657, 685.

${ }^{76}$ It is noticeable that Weiser, another skilled Indian agent, did not use term 'Covenant Chain, let alone recount its history. For example, during the Treaty of Logstown Weiser, when translating Tanaghrisson's Covenant Chain narrative, refers to the Chain as the 'chain of friendship', see MPCP, V, 353.

${ }^{77} D R C H N Y, \mathrm{VII}, 19$, see also DRCHNY, VI, 314, 385.

${ }^{78} \mathrm{PWJ}, \mathrm{II}, 340$.
} 
cemented ties by his common-law marriage to Molly Brant, a Mohawk woman. This relationship considerably elevated Johnson's status among the Mohawk as Molly was the stepdaughter of Brant Kanagaradunkwa, a highly influential and powerful Canajoharie headman. By marrying and having children with Molly, Johnson entered into Mohawk networks of kinship. Such relations enabled Johnson to develop an exceptionally nuanced understanding of Haudenosaunee diplomatic protocol, knowledge which shaped his diplomatic interactions with the Six Nations. Johnson's frequent use of gift giving, wampum, metaphorical language, his performance of the condolence ceremony and, on occasions, his choice to dress in indigenous attire, enabled him to appeal Haudenosaunee values, enhance his personal status and conduct successful negotiations beneficial to New York and the Crown.

Although Johnson's cultural immersion strategy was motivated by self-interest his adherence to indigenous diplomatic protocol was also driven by the knowledge that this was the only way to gain the trust of the Six Nations that was vital to the conduct of successful diplomacy. Although Johnson's opinions concerning indigenous sovereignty are complex and somewhat inconsistent, changing based on his audience, he likely considered the Haudenosaunee as 'nominal' rather than 'actual subjects'. ${ }^{79}$ Such beliefs likely stemmed from how indigenous groups understood their place within intercultural alliances. For example, in a letter reviewing Indian affairs in 1767, Johnson explained that indigenous nations consider themselves 'free people' and have no words to express submission. ${ }^{80}$ Accounts which describe Haudenosaunee using the term subject in reference to themselves are 'erroneous', Johnson argued, 'for the very word would have startled them, had ever been pronounced by any interpreter' ${ }^{81}$ The term, Johnson explained, would have caused great resentment, possibly even war, for they consider themselves 'no more than our friends and allies' ${ }^{82}$ Such comments reveal that indigenous representation as subjects in legal documentation was for

\footnotetext{
${ }^{79} \mathrm{PWJ}, \mathrm{IV}, 863$.

${ }^{80}$ DRCHNY, VII, 958, see also PWJ, IV, 616.

${ }^{81}$ Ibid., 561.

${ }^{82}$ Ibid., 958, 852, see also PWJ, IV, 616.
} 
the benefit of the Crown and Whitehall, as no actual words of subjection were uttered in treaty councils. Johnson was arguing that the portrayal of British-indigenous relations depicted in treaty documentation did not reflect the reality on the ground, in which the Crown possessed little or no direct authority over native peoples.

Johnson, to a certain extent, also understood what indigenous groups considered as their sovereign rights, and how they articulated them during intercultural diplomacy. In a letter to the Lords of Trade Johnson explained how the Haudenosaunee believed they had ancient rights to the territory in which they inhabit, and how they considered the Northern parts of North America as their 'sole property. ${ }^{\prime 83}$ Although they accepted French and British settlements due to trade they never 'understood such settlement as a dominion', Johnson informed, for 'neither we, nor the French ever made a conquest over them. ${ }^{184}$ Such comments are reminiscent of how Canasatego defined territorial rights to the Potomac in response to Maryland's claim to right of purchase. In fact, Johnson continued, the Haudenosaunee were highly 'amused' by French and British claims that the Seven Years War was fought for the 'protection of Indian rights'. For as the war went on it became clear to the Six Nations that war was fought by the British and French to 'see who would become masters of what was the property of neither one nor the other. ${ }^{85}$

Not only did the Haudenosaunee define their sovereignty in relation to ancestral right to territory and right of conquest but they also expressed their independence in relation to their ability to protect themselves. For as Johnson noted, the Haudenosaunee scorn our offers of protection 'answering constantly, that they are not in want of it. ${ }^{\prime 86}$ The British, as was common in periods defined by overlapping spheres of influence, frequently invoked the terminology of protection to describe arrangements of power across polities. Although the Haudenosaunee accepted, and even sought, British protection in certain contexts this did not mean, at least in their minds, that they gave

\footnotetext{
${ }^{83}$ DRCHNY, VII, 575.

${ }^{84} \mathrm{lbid}$.

${ }^{85} \mathrm{lbid}$.

${ }^{86} \mathrm{lbid}$., 958.
} 
up their sovereign independence. Protection, the Haudenosaunee believed, was simply an obligation of alliance. What the Haudenosaunee objected to was attempts by the British to use this framework of protection to reclassify allies as subjects. ${ }^{87}$ What drove indigenous comments about not desiring protection was perhaps British claims to a sole capacity to protect. Neither group, as Johnson himself readily admitted, could claim such powers in the mid-eighteenth century. ${ }^{88}$

Johnson's nuanced understandings of indigenous self-perceptions of their sovereignty and rights led him to adopt the Covenant Chain narrative to achieve British diplomatic aims. The use of this extremely powerful metaphor he knew would appeal to Haudenosaunee sentiments. As Jesuit Father Paul LeJeune argued in 1636, when speaking of indigenous diplomacy, 'metaphor is largely in use among these peoples; unless you accustom yourself to it, you will understand nothing of their councils, where they speak almost entirely in metaphors' ${ }^{89}$ Johnson took this advice once step further, for not only did he familiarise himself with indigenous metaphorical speech, but he strategically employed certain aspects of it during diplomatic transactions.

In 1748, when serving as New York's agent to the Haudenosaunee, Johnson used the Covenant Chain narrative to great effect during a council meeting at Onondaga. Johnson's journey to Onondaga, his first formal introduction to the Grand Council, was undertaken with the intention of persuading the Six Nations not to travel to Canada to rescue their relatives held captive by the French. The previous year a Six Nations delegation requested, and was granted, Johnson's permission to go to Canada to release their relatives. The delegation however had stayed all summer and returned home with no captives, leading Johnson to believe they were conducting other business with the French. ${ }^{90}$ Although Johnson was to forbid the Six Nations from undertaking this journey again, he would promise that New York authorities would secure the release of their kin. Johnson began his address to the Grand Council at Onondaga with a historical account of the

\footnotetext{
${ }^{87}$ Lauren Benton and Adam Clulow, 'Empires of protection: Making interpolity law in the early modern world', Journal of Global History, Vol. 12, 86.

${ }^{88}$ DRCHNY, VII, 561.

${ }^{89}$ Reuben Gold Thwaites (ed.), The Jesuit Relations and Allied Documents, X, 219.

${ }^{90} \mathrm{PWJ}, \mathrm{I}, 160$.
} 
'brothership' between the British and the Six Nations. The reasoning for this, Johnson argued, was that 'there are several among you who seem to forget it'. Johnson then stated that they may find a foreigner knowing this narrative strange but that he had learnt the history of their relationship from 'some old writings of our forefathers. ${ }^{.91}$ Here Johnson sought to demonstrate, to the Grand Council, that the customs of Haudenosaunee diplomacy would continue to be observed. By reciting the history of the Covenant Chain Johnson was demonstrating his awareness that this had been, and would remain, the key structuring element of their relationship.

As with the previous examples, Johnson recounted the history of the Six Nations relationship with the Dutch, then the British and demonstrated how it had grown stronger over time by detailing the change in the Chain's material and the change in durability of the object that the Chain was tied to. The Chain had bound their societies together and created a 'brothership' in which they shared 'one heart, one head and one blood'. After 'foreseeing the many advantages both sides would reap' their forefathers had agreed that if the 'Chain should turn the least rusty, offer to slip or break, that it should be immediately brightened up again, and not let it slip or break on any account' ${ }^{92}$ Stating that both sides made the decision to continue the mutually advantageous relationship and protect it from harm was a calculated choice of words by Johnson for it demonstrated he understood theirs was a relationship formed between sovereign powers. Knowing the Six Nations did not perceive of themselves as subjects led Johnson to formulate a speech that would appeal to their understandings of the Covenant Chain.

Using the Covenant Chain allowed Johnson to demonstrate, to the Six Nations, that he fully understood the nature of alliance and the question of reciprocal obligations. In relation to the Six Nations delegation who travelled to Canada, Johnson argued that the French had tried to blindfold them and get them to slip their hands out of the Chain. Chastising the Six Nations for their behaviour Johnson argued they should no longer listen to the 'deceitful French... but stick fast to the Old

\footnotetext{
${ }^{91}$ Ibid., 158.

${ }^{92}$ lbid.
} 
Agreement. ${ }^{\prime 93}$ Like Canasatego and Taraghrisson, he was claiming the actions of one party were threatening to break the alliance their forefathers had created. The fact that Johnson narrated the history of their relationship before he issued Governor of New York's demands gave his words greater authority. Narrating the history of their mutually beneficial long-standing alliance allowed Johnson to argue the Six Nation's desire to travel to Canada, to rescue their relatives, was in opposition to their alliance. It further allowed Johnson to accuse the Six Nations of being neither 'sincere or hearty in your Brothers cause' ${ }^{94}$ Through his use of the Chain metaphor Johnson was seeking to illustrate his understanding of the Haudenosaunee concept of alliance as a careful balance of autonomy and obligation. It enabled him to request that the Six Nations adhere to the New York Governor's demand and not travel to Canada, for the Chain's central idea was that sovereignty was not only the freedom to act autonomously but was also the recognition of obligations to another power.

\section{Conclusion}

Analysis of the contexts in which the Covenant Chain narrative was employed, by both the Haudenosaunee and the British, reveals it was much more than a political principle governing intercultural relations, or a metaphorical speech-act for establishing and renewing alliances. It was a powerful communicative mechanism for asserting sovereign identity and rights, instrumental in an era where overlapping sovereignties were the rule rather than the exception. For the Haudenosaunee, the Covenant Chain narrative was a means to articulate sovereign independence in relation to conceptual understandings of alliance, obligation, and place. Today the Covenant Chain continues to shape Haudenosaunee understandings of their relationship with the American and Canadian state. It is a living history which encapsulates the idea of political autonomy and mutual obligation. In the period analysed the narrative's force was rooted in the diplomatic contexts in which it was applied, enabling the Haudenosaunee, on the occasions analysed, to challenge British

\footnotetext{
${ }^{93} \mathrm{PWJ}, \mathrm{I}, 159$.

${ }^{94}$ Ibid., 161.
} 
territorial claims, rebuke actions which undermined the foundations upon which alliances were based, and demand specific sovereign rights. For Johnson the Chain provided a means of articulating British political power in a way that appealed to Haudenosaunee sensibilities and a means of furthering imperial, and personal, ambition. Only by expanding the scope of history to include utterances and communicative strategies of indigenous groups can we truly understand the complex diplomatic realities that existed in early America. Paying closer attention to the mechanisms by which indigenous people expressed sovereignty, such as the Covenant Chain narrative, allows us to develop our understanding of how sovereign identity was constructed and asserted during eighteenth century intercultural diplomacy. 